\title{
Is reticular temperature a useful indicator of heat stress in dairy cattle?
}

\author{
S. Ammer, ${ }^{* 1}$ C. Lambertz, $†$ and M. Gauly $†$ \\ *Department of Animal Sciences, Georg-August-University, 37075 Goettingen, Germany \\ †Faculty of Science and Technology, Free University of Bolzano, 39100 Bolzano, Italy
}

\section{ABSTRACT}

The present study investigated whether reticular temperature (RT) in dairy cattle is a useful indicator of heat stress considering the effects of milk yield and water intake (WI). In total, 28 Holstein-Friesian dairy cows raised on 3 farms in Lower Saxony, Germany, were studied from March to December 2013. During the study, RT and barn climate parameters (air temperature, relative humidity) were measured continuously and individual milk yield was recorded daily. Both the daily temperature-humidity index (THI) and the daily median RT per cow were calculated. Additionally, the individual WI (amount and frequency) of 10 cows during $100 \mathrm{~d}$ of the study was recorded on 1 farm. Averaged over all farms, daily THI ranged between 35.4 and 78.9 with a mean ( \pm standard deviation) of 60.2 $( \pm 8.7)$. Dairy cows were on average $( \pm$ standard deviation) $110.9 \mathrm{~d}$ in milk $( \pm 79.3)$ with a mean ( \pm standard deviation) milk yield of $35.2 \mathrm{~kg} / \mathrm{d}( \pm 9.1)$. The RT was affected by THI, milk yield, days in milk, and WI. Up to a THI threshold of 65 , RT remained constant at $39.2^{\circ} \mathrm{C}$. Above this threshold, RT increased to $39.3^{\circ} \mathrm{C}$ and further to $39.4^{\circ} \mathrm{C}$ when THI $\geq 70$. The correlation between THI $\geq 70$ and RT was 0.22 , whereas the coefficient ranged between $\mathrm{r}=-0.08$ to +0.06 when THI $<70$. With increasing milk yield, RT decreased slightly from $39.3^{\circ} \mathrm{C}(<30 \mathrm{~kg} / \mathrm{d})$ to $39.2^{\circ} \mathrm{C}(\geq 40 \mathrm{~kg} / \mathrm{d})$. For daily milk yields of $\geq 40 \mathrm{~kg}$, the median RT and daily milk yield were correlated at $\mathrm{r}=-0.18$. The RT was greater when dairy cows yielded $\geq 30 \mathrm{~kg} / \mathrm{d}$ and THI $\geq 70\left(39.5^{\circ} \mathrm{C}\right)$ compared with milk yields $<30 \mathrm{~kg}$ and THI $<70\left(39.3^{\circ} \mathrm{C}\right)$. The WI, which averaged ( \pm standard deviation) $11.5 \mathrm{l}( \pm 5.7)$ per drinking bout, caused a mean decrease in RT of $3.2^{\circ} \mathrm{C}$ and was affected by the amount of WI $(\mathrm{r}=0.60)$. After WI, it took up to $2 \mathrm{~h}$ until RT reached the initial level before drinking. In conclusion, RT increased when the THI threshold of 65 was exceeded. A further increase was noted when

Received April 6, 2016.

Accepted August 4, 2016.

${ }^{1}$ Corresponding author: stefanie.ammer@agr.uni-goettingen.de
THI $\geq 70$. Nevertheless, the effects of WI and milk yield have to be considered carefully when RT is used to detect hyperthermia in dairy cattle.

Key words: heat stress, reticular temperature, performance, water intake

\section{INTRODUCTION}

The predicted climate change will intensify the exposure of animals to heat stress even in moderate climatic zones of Central Europe (Gauly et al., 2013). This is of special importance for high-yielding dairy cattle that are commonly kept in outdoor barns. They are directly exposed to the ambient climatic conditions and have an excessive thermal load due to their metabolic performance. Heat stress may affect performance (Lambertz et al., 2014), feed intake (West et al., 2003), as well as health, reproduction, and welfare (Renaudeau et al., 2012). To estimate the effects of the climatic conditions, generally the air temperature or the temperaturehumidity index (THI), a combination of temperature and relative humidity (RH), are commonly used (Bohmanova et al., 2007). For the THI, a heat stress threshold of 70 was found under subtropical/tropical conditions (Kadzere et al., 2002), whereas studies conducted under moderate climate zones found negative effects already at THI values of 60 (Brügemann et al., 2012). Dairy cows respond to heat stress conditions with physiological changes (i.e., an increasing peripheral blood flow and higher respiratory and sweating rates) to enhance heat dissipation (West, 2003). However, this evaporative heat release is limited when the upper critical air temperature is exceeded. Hyperthermia and a rising core body temperature (BT) occur as a result of limited evaporative heat release (Berman et al., 1985). Changes in BT are supposed to predict heat stress conditions in dairy cattle. Dikmen and Hansen (2009) found a correlation between rectal temperature and ambient THI of $\mathrm{r}=0.5$. In the study of Berman et al. (1985) rectal temperature increased up to $0.2^{\circ} \mathrm{C}$ per $1^{\circ} \mathrm{C}$ increase in temperature during hot conditions $(26$ to $36^{\circ} \mathrm{C}$ ). This finding was confirmed by Srikandakumar and Johnson (2004), who determined a significant 
increase of the rectal temperature from 39.2 to $39.7^{\circ} \mathrm{C}$ when temperature rose from 24 to above $35^{\circ} \mathrm{C}$.

Under practical conditions, manual recordings of rectal or vaginal temperatures are still the most common methods to determine BT in dairy cows, because of the low costs and ease of measurement (Hicks et al., 2001; Bewley et al., 2008a). However, the methods are time and labor consuming and bear the risk of operator errors or injuries (Bewley et al., 2008a). Therefore, several studies investigated the use of the intraruminal sensor to measure BT. Sensors are placed in the reticulum and enable an automatic, continuous, and labor-extensive monitoring of the reticular temperature (RT; e.g., Hicks et al., 2001; Bewley et al., 2008a; Liang et al., 2013). Bewley et al. (2008a) found a mean $( \pm$ SD) RT of $39.3^{\circ} \mathrm{C}( \pm 0.41)$, whereas Brown-Brandl et al. (2003) observed a lower mean RT $( \pm \mathrm{SD})$ of $38.7^{\circ} \mathrm{C}( \pm 0.4)$ and Liang et al. (2013) a greater value of $40.1^{\circ} \mathrm{C}( \pm 0.32)$. The RT and rectal temperatures were correlated at $\mathrm{r}$ $=0.65$, estimated by Bewley et al. (2008a), and were influenced by seasonal variations. In addition, Liang et al. (2013) observed an effect of climatic conditions on RT and found the greatest RT in summer $\left(40.4^{\circ} \mathrm{C}\right)$, when compared with spring, fall (both $40.1^{\circ} \mathrm{C}$ ), and winter $\left(40.0^{\circ} \mathrm{C}\right)$. However, there are additional effects on the RT values, which have to be considered when interpreting the measurements. First, RT is generally greater compared with other BT as a result of heat produced during fermentation (Bewley et al., 2008a). Second, RT may be influenced by water intake (WI). Bewley et al. (2008b) found a maximum decrease in RT of $9.2^{\circ} \mathrm{C}$ after WI and a duration of more than 3 $\mathrm{h}$ until RT returned to the initial level recorded before drinking, depending on the amount of WI and water temperature. Third, as milk production in dairy cattle is associated with a metabolic heat increment and highyielding cows are suggested to be more sensitive to heat stress (Renaudeau et al., 2012), animal performance might be a main factor that determines RT (Liang et al., 2013). Therefore, the objectives of this study were to (1) investigate whether RT can be used as an indicator of heat stress under moderate climatic conditions and (2) study the influences of WI and milk yield on RT in high-yielding dairy cattle.

\section{MATERIALS AND METHODS}

The study was conducted from March until December 2013 including in total 28 Holstein-Friesian dairy cows raised on 3 farms in Lower Saxony, Germany. Farm 1 was an experimental farm of the Chamber of Agriculture Lower Saxony with a herd size of 75 lactating cows, farm 2 was an experimental farm of the Institute of Animal Nutrition of the Friedrich-Loeffler-Institute with 120 lactating cows, and farm 3 was a commercial dairy farm with a herd size of 60 lactating cows. Farms were chosen based on following criteria: (1) husbandry system: loose-housing barns equipped with cubicles and natural roof ventilation without access to pasture; (2) dairy cow breed: Holstein Friesian; (3) the required provision of the daily milk yield records per cow; and (4) the opportunity to collect the data by using sensor technology within the farm. Exclusively on farm 1, the barn was additionally equipped with fans installed above the feed alley.

For the trial, 12, 10, and 6 cows of farms 1, 2, and 3 were used, respectively. As on farm 2 calving season was set seasonally, lactation stage was similar for each cow. On farm 1, study cows could be equipped with the temperature bolus before calving; thus, each cow was at first DIM at the start of the study, as data before calving were not considered. Selected cows on farm 3 were distributed consistently within the first third of the lactation period, to include cows representative for each lactation stage within the whole study. Thus, on farm 1 data were recorded from first DIM, whereas on farm 2 and 3 mean $( \pm$ SD) DIM was $165( \pm 27)$ and 50 $( \pm 36)$, respectively, at the beginning of data recording. The lactation number ranged from 1 to 4 on farms 1 and 3 and from 3 to 7 on farm 2 .

Milking process on farm 1 was conducted either twice daily in a milking parlor (late lactating cows) or in an automatic milking system with a mean frequency of 2.7 milkings/d (early lactating cows) of the herd. On farm 2 and 3, cows were milked twice daily in a milking parlor. On all farms, animals received a TMR ad libitum, similar in composition per each farm.

\section{Data Recording}

The start of the data recording differed between the farms, whereas the period from June to July, in which heat stress conditions are expected (Lambertz et al., 2014), was covered on each of the farms. The end of the measuring period varied depending on the battery lifetime for each single bolus system. In detail, data were recorded from March to November on farm 1, from May to July on farm 2, and from June to December on farm 3. Individual daily milk yield was recorded and classified as follows: $<30 \mathrm{~kg}, \geq 30$ to $<35 \mathrm{~kg}, \geq 35$ to $<40 \mathrm{~kg}$, and $\geq 40 \mathrm{~kg}$.

Barn climatic conditions including temperature (in ${ }^{\circ} \mathrm{C}$ ) and $\mathrm{RH}$ (in \%) were recorded by using a total of 17 Tinytag Data Loggers (Tinytag Plus 2 TGP-4500; Gemini Data Loggers Ltd., West Sussex, UK). Nine loggers were installed on farm 1 and 4 each on the other 2 farms. They were installed at heights of 1.2 to $3 \mathrm{~m}$ distributed throughout the barns. Temperature and $\mathrm{RH}$ 
were recorded at 10- to 15-min intervals. Records of all loggers per farm were averaged for each time point and used to calculate THI according to the following formula:

$$
\begin{aligned}
\mathrm{THI}=(1.8 \times & \mathrm{T}+32)-(0.55-0.0055 \times \mathrm{RH}) \\
& \times(1.8 \times \mathrm{T}-26),
\end{aligned}
$$

where $\mathrm{T}$ is the air temperature in ${ }^{\circ} \mathrm{C}$ and $\mathrm{RH}$ is the relative humidity in \% (NRC, 1971). Daily THI was classified as follows: $<60, \geq 60$ to $65, \geq 65$ to 70 , and $\geq 70$.

The RT was recorded by using the smaXtec $\mathrm{pH} \&$ Temp Sensor (smaXtec animal care sales GmbH, Graz, Austria). The bolus with a dimension of $132 \times 35 \mathrm{~mm}$ contains a microprocessor, a memory space, an internal antenna, and a battery. The boluses are break-proof and resistant to rumen fluid. They were delivered orally with a balling gun in the reticulum. According to the manufacturer, it can be assumed that they remained in the reticulum throughout the study period when delivered in this way. The RT was recorded at 10-min intervals. Records were read out wirelessly and converted into an Excel file (Microsoft Corp., Redmond, WA) by using a mobile reader. On farm 1,2 animals left the herd in August; thus, data for both animals were not available from study d 162 on.

Referring to Bewley et al. (2008b), RT values below 32 and above $43^{\circ} \mathrm{C}(\mathrm{n}=488)$ were deleted as these extremes were assumed to be measurement errors and not representative for the physiological status of the cow. Additionally, data of one cow, which showed fever (consistently $40^{\circ} \mathrm{C}$ RT with concurrent decline in milk yield) for $10 \mathrm{~d}$, were excluded. In total, the data set consisted of $\mathrm{n}=374,439,95,818$, and 117,208 single RT measurements for farms 1,2 , and 3 , respectively. Following results of the methodical study of Ammer et al. (2016), which showed that median RT values were more highly correlated with vaginal and rectal temperature than arithmetic means, hourly median $(\mathrm{n}=80,548)$, and daily median $(\mathrm{n}=3,339)$ values were calculated.

In addition, WI was monitored for 10 cows on farm 2 from May to July 2013 using 4 automatic drinking troughs (RIC system, Insentec BV, Marknesse, the Netherlands), which were connected to a computer system. An antenna, installed above the water troughs, identified the cows' ear transponder whenever it approached a trough. The cow number, trough number, and time of visit as well as the trough weight difference for each individual visit were recorded. Water troughs filled up automatically after every drinking event. A total number of 5,043 drinking bouts (trough visit) with a minimum intake of $0.1 \mathrm{l}$ were detected. Bouts were classified as $\leq 5 \mathrm{~L},>5$ to $10 \mathrm{~L},>10$ to $15 \mathrm{~L}$, and $>15 \mathrm{~L}$.

\section{Statistical Analysis}

Statistical analyses were conducted by using the statistical software package SAS, version 9.3 (SAS Institute Inc., Cary, NC). Barn climatic conditions (temperature and THI) were merged with RT records. Two linear mixed models were developed to estimate the effects of milk yield, DIM, as well as THI on the daily median RT. To test the significance of the continuously recorded parameters on daily median RT, the MIXED procedure was used. Parameter estimates for fixed effects were displayed using the SOLUTION option with the following model:

$$
\begin{aligned}
& \mathrm{Y}_{\mathrm{ijklmn}}=\mu+\mathrm{Farm}_{\mathrm{i}}+\mathrm{DIM}_{\mathrm{j}}+\mathrm{MY}_{\mathrm{k}}+\mathrm{THI}_{\mathrm{l}} \\
& +(\mathrm{DIM} \times \mathrm{MY} \times \mathrm{THI})_{\mathrm{jkl}}+\mathrm{Cow}_{\mathrm{m}}+\mathrm{e}_{\mathrm{ijklmn}},
\end{aligned}
$$

where $Y_{\mathrm{ijklmn}}=$ nth observation of daily median RT; $\mu$ $=$ overall mean; Farm $_{\mathrm{i}}=$ fixed effect of farm $(\mathrm{i}=1,2$, 3); $\mathrm{DIM}_{\mathrm{j}}=$ fixed effect of DIM; $\mathrm{MY}_{\mathrm{k}}=$ fixed effect of daily milk yield; $\mathrm{THI}_{1}=$ fixed effect of daily THI; (DIM $\times \mathrm{MY} \times \mathrm{THI})_{\mathrm{jkl}}=3$-way interaction between DIM, milk yield, and daily THI; $\mathrm{Cow}_{\mathrm{m}}=$ random effect of $\operatorname{cow}(\mathrm{m}=1$ to 28$)$; and $\mathrm{e}_{\mathrm{ijk} k \mathrm{mn}}=$ residual error with a first-order autoregressive autocorrelation structure.

In the second model fixed effects for farm, milk yield, THI, and covariable for DIM were included by using the above-mentioned classification for milk yield and THI with the following model (Proc MIXED):

$$
\begin{gathered}
\mathrm{Y}_{\mathrm{ijklmn}}=\mu+\mathrm{Farm}_{\mathrm{i}}+\mathrm{MYcl}_{\mathrm{j}}+\mathrm{THIcl}_{\mathrm{k}}+\mathrm{DIM}_{\mathrm{l}} \\
+\mathrm{Cow}_{\mathrm{m}}+\mathrm{e}_{\mathrm{ijklmn}},
\end{gathered}
$$

where $\mathrm{Y}_{\mathrm{ijk}} \mathrm{mn}=$ nth observation of daily median RT; $\mu$ $=$ overall mean; Farm $_{\mathrm{i}}=$ fixed effect of farm $(\mathrm{i}=1,2$, 3); $\mathrm{MYcl}_{\mathrm{j}}=$ fixed effect of milk yield class $(\mathrm{j}=<30 \mathrm{~kg}$; $\geq 30$ to $35 \mathrm{~kg}, \geq 35$ to $40 \mathrm{~kg}$, and $\geq 40 \mathrm{~kg}$ ); THIcl $_{\mathrm{k}}=$ fixed effect of daily THI class $(\mathrm{k}=<60, \geq 60$ to $65, \geq 65$ to 70 , and $\geq 70) ; \mathrm{DIM}_{1}=$ covariable of DIM; $\mathrm{Cow}_{\mathrm{m}}=$ repeated effect of cow $(\mathrm{m}=1$ to 28$)$; and $\mathrm{e}_{\mathrm{ijklmn}}=$ random residual. The significance of the fixed effects was analyzed by using the Tukey test with a significance level of $P<0.05$. Results are presented as least squares means \pm standard error.

For estimating the effect of WI on RT, the 2 measurements of RT before each drinking bout were averaged as initial RT level. The differences between the initial RT level and the $12 \mathrm{RT}$ records after each drinking bout 
were calculated. Based on these records, the duration until RT reached the initial level before drinking was computed. Descriptive statistics were displayed using Proc MEANS and the distribution using Proc FREQ. The MIXED procedure was used to estimate the effect of the WI amount on RT with the following statistical model:

$$
\mathrm{Y}_{\mathrm{ijkl}}=\mu+\operatorname{Rec}_{\mathrm{i}}+\mathrm{Wa}_{\mathrm{j}}+\mathrm{Cow}_{\mathrm{k}}+\mathrm{e}_{\mathrm{ijkl}},
$$

where $Y_{\mathrm{ijkl}}=$ the lth difference between RT before and after WI; $\mu=$ overall mean; Rec $_{i}=$ fixed effect of record number after WI $(\mathrm{i}=1$ to 12$) ; \mathrm{Wa}_{\mathrm{j}}=$ water amount per intake $(\mathrm{j}=\leq 5 \mathrm{~L} ;>5$ to $10 \mathrm{~L} ;>10$ to $15 \mathrm{~L} ;>15$ $\mathrm{L}) ; \mathrm{Cow}_{\mathrm{k}}=$ repeated effect of cow $\mathrm{k}(\mathrm{k}=1$ to 10$)$; and $\mathrm{e}_{\mathrm{ijkl}}=$ random residual. Comparisons were performed using the Tukey test with a significance level of $P<$ 0.05 . Results are presented as least squares means \pm standard error. The Kenward-Roger approximation for the degrees of freedom was used. Pearson correlation coefficients were estimated by using Proc CORR.

\section{RESULTS AND DISCUSSION}

\section{Effect of Climatic Conditions on Reticular Temperature}

Averaged over the 3 farms, temperature ranged from -6.3 to $34.1^{\circ} \mathrm{C}$ during the study period, with a mean $( \pm \mathrm{SD})$ of $16.1^{\circ} \mathrm{C}( \pm 6.3$; Table 1$)$. Accordant THI values varied from 9.6 to 84.9 with an average $( \pm \mathrm{SD})$ of 60.2 $( \pm 9.6)$. The fact that fans were only installed on farm 1 might have led to varying environmental conditions due to changes in air movement, which were not recorded in this study. Though air movement is recommended to be considered whenever the environmental conditions in dairy barns are evaluated, its practical application is limited and the THI has been proven to be a feasible indicator for heat stress conditions (Bohmanova et al., 2007). Given that THI inside the barn was measured, changes in climatic conditions due to the use of fans were taken into consideration.
The climatic conditions measured in this study are characteristic for temperate climates and are similar to those THI values recorded previously in the same region (Brügemann et al., 2012; Lambertz et al., 2014). Given the threshold for heat stress of THI $=60$ (Brügemann et al., 2012) and 70 (Kadzere et al., 2002), the cows used in the study were exposed to heat stress over a considerable period. Overall, mean $( \pm \mathrm{SD}) \mathrm{RT}$ was $38.8^{\circ} \mathrm{C}( \pm 1.1)$, whereas other authors found a greater mean RT of $39.3^{\circ} \mathrm{C}$ under continental conditions (Bewley et al., 2008a). Under humid-subtropical conditions, Liang et al. (2013) found a mean RT of $40.1^{\circ} \mathrm{C}$. When comparing these results with the present study, it has to be noted that in both cited studies low RT measurements, which were supposed to be the results of WI, were removed from the data set. In the study of Bewley et al. (2008a), all values below $37.81^{\circ} \mathrm{C}$ were excluded. Contrarily, in the current study, these values were included, which might partly explain the lower mean RT. The daily median RT was calculated and averaged $( \pm \mathrm{SD}) 39.1^{\circ} \mathrm{C}( \pm 0.4)$. As recently shown by Ammer et al. (2016), the median RT value was more highly correlated with vaginal $(\mathrm{r}=0.53)$ and rectal $(\mathrm{r}=0.48)$ temperatures compared with the mean RT. Thus, the median was proposed to be a more reliable indicator of RT. Consequently, median RT values were used in the present study. Temperatures in the forestomach are generally about $0.5^{\circ} \mathrm{C}$ greater, when compared with other BT locations, caused by the heat that is produced by microorganisms (Bewley et al., 2008b). Thus, the median RT in the present study was $0.3^{\circ} \mathrm{C}$ greater than the mean rectal temperature of $38.8^{\circ} \mathrm{C}$, found by Bewley et al. (2008a).

Daily mean THI affected the daily median RT $(P<$ 0.001; Table 2). Figure 1 presents the diurnal course of the hourly median RT separated by different ambient daily THI conditions. Across all THI classes, lowest RT was observed between 0800 to $0900 \mathrm{~h}$, whereas greatest values occurred between 0000 and $0500 \mathrm{~h}$. Consistently, other studies reported lower BT in the morning and greater values in the evening and during the night (Bitman et al., 1984; Liang et al., 2013). Additionally, the

Table 1. Descriptive statistics of DIM, milk yield, reticular temperature (RT; $n=28$ cows), and barn climatic parameters

\begin{tabular}{lrccc}
\hline Item & Mean & SD & Minimum & Maximum \\
\hline Temperature,$~^{\circ} \mathrm{C}$ & 16.1 & 6.3 & -6.3 & 34.1 \\
THI $^{1}$ & 60.2 & 9.6 & 24.2 & 84.9 \\
Daily mean THI & 60.2 & 8.7 & 35.4 & 78.9 \\
RT, ${ }^{\circ} \mathrm{C}$ & 38.8 & 1.1 & 32.0 & 43.0 \\
Daily median RT, ${ }^{\circ} \mathrm{C}$ & 39.1 & 0.4 & 38.0 & 41.6 \\
DIM & 110.9 & 79.3 & 0 & 285 \\
Daily milk yield, $\mathrm{kg}$ & 35.2 & 9.1 & 0 & 75 \\
\hline
\end{tabular}

${ }^{1}$ THI = temperature-humidity index. 


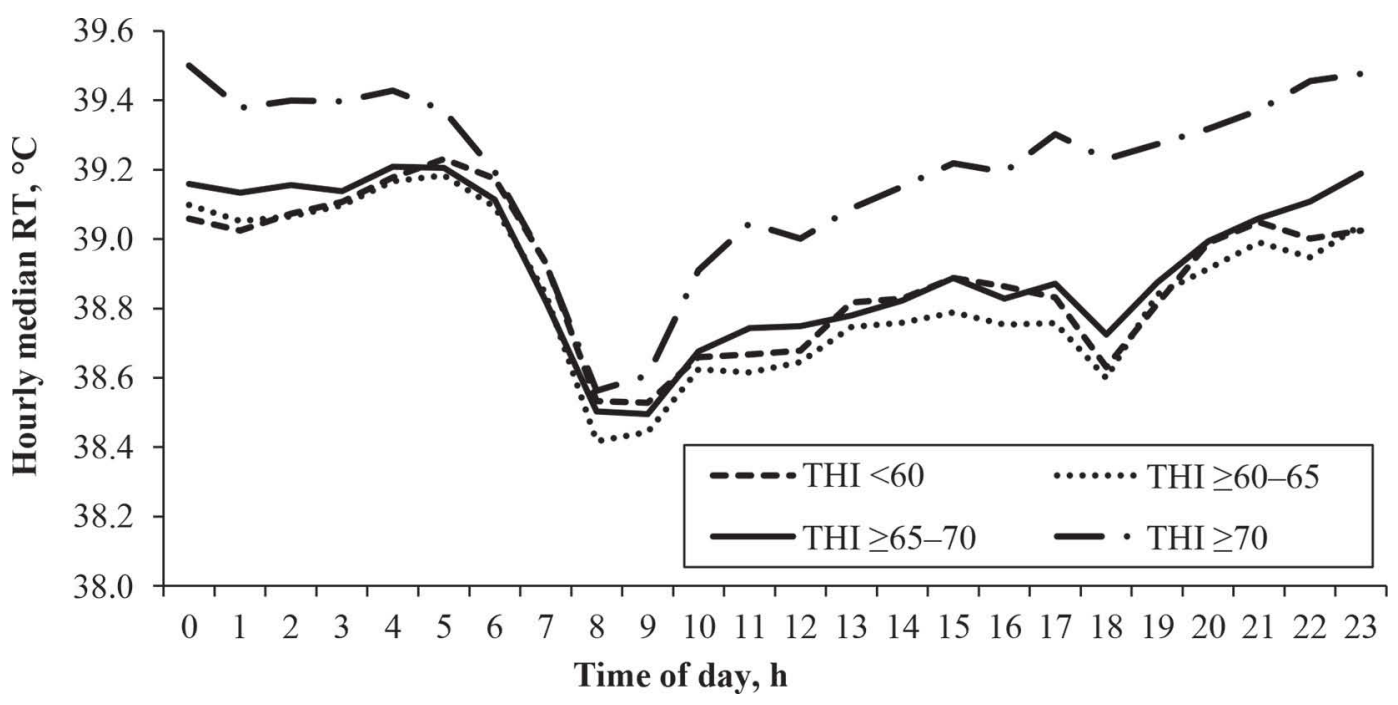

Figure 1. Diurnal course of hourly median reticular temperature (RT; $n=28$ cows) in dependence of the daily mean temperature-humidity index (THI) class.

authors observed lower BT in the afternoon, similar to the courses in the present results when ambient THI was $<70$. Whenever the diurnal course of RT is discussed, it has to be noted that possible farm effects such as the milking times or nutrition might affect measurements. For example, Araki et al. (1984) reported that vaginal temperature decreased after milking and increased following feed intake. Approximately $60 \mathrm{~min}$ after entering the milking parlor, the minimum vaginal temperature was observed and assumed to be caused by the shade within the parlor as well as the heat dissipation through milk removal (Araki et al., 1984). Liang et al. (2013) showed a diurnal RT rhythm, though the effects of milking were not quantified. The fact that some animals were milked in an automatic milking system with a milking frequency of about 2.7 times/d on farm 1 partly limits the representativeness of this study. Next to the milk yield, it is warranted to study the effects of milking on RT in more detail in further studies. Additionally, the effects of diet composition on $\mathrm{RT}$, as a result of variable heat production through fermentation (West, 1999), remain unclear from this study. For instance, a high total net energy intake increases metabolic heat production and is more critical than the effect of fiber amount or digestibility in the diet (West et al., 1999). High-yielding cows, as used in the present study, require a high dietary energy density, which consequently might lead to increasing RT.

The daily median RT increased from THI classes $<60$ and $\geq 60$ to $65\left(39.2^{\circ} \mathrm{C}\right)$ to the class $\geq 65$ to $70\left(39.3^{\circ} \mathrm{C}\right.$; $P<0.001)$ and further when THI $\geq 70\left(39.4^{\circ} \mathrm{C} ; P<\right.$ 0.001; Figure 2). Consistently, Liang et al. (2013) found a greater mean RT during hot conditions in the summer season $\left(40.4^{\circ} \mathrm{C}\right)$ in comparison to spring, autumn $\left(40.1^{\circ} \mathrm{C}\right)$, and winter $\left(40.0^{\circ} \mathrm{C}\right)$. Likewise, Nabenishi et al. (2011), who observed vaginal temperatures, found a greater BT-level during summer, when compared with colder seasons. Contrarily, significantly lower mean RT

Table 2. Test of significance of effects on daily median reticular temperature (RT) of dairy cows (n $=28)$

\begin{tabular}{llcc}
\hline Effect & Coefficient & $\mathrm{SE}$ & $P$-value \\
\hline Intercept & 40.63 & 0.21 & $<0.001$ \\
Farm & & & $<0.001$ \\
1 & -0.61 & 0.15 & - \\
2 & 0 & 0.21 & 0.460 \\
3 & $-1.45 \times 10^{-2}$ & $2.78 \times 10^{-3}$ & $<0.001$ \\
Daily mean THI ${ }^{1}$ & $5.34 \times 10^{-4}$ & $7.00 \times 10^{-5}$ & $<0.001$ \\
Daily mean THI $\times$ milk yield, kg & $6.20 \times 10^{-5}$ & $9.95 \times 10^{-6}$ & $<0.001$ \\
Daily mean THI $\times$ DIM & $-3.77 \times 10^{-2}$ & $4.4 \times 10^{-3}$ & $<0.001$ \\
Milk yield, kg & $-4.38 \times 10^{-3}$ & $5.86 \times 10^{-4}$ & $<0.001$ \\
DIM & $-3.00 \times 10^{-5}$ & $8.83 \times 10^{-6}$ & 0.004 \\
DIM $\times$ milk yield, kg & & &
\end{tabular}

${ }^{1} \mathrm{THI}=$ temperature-humidity index. 


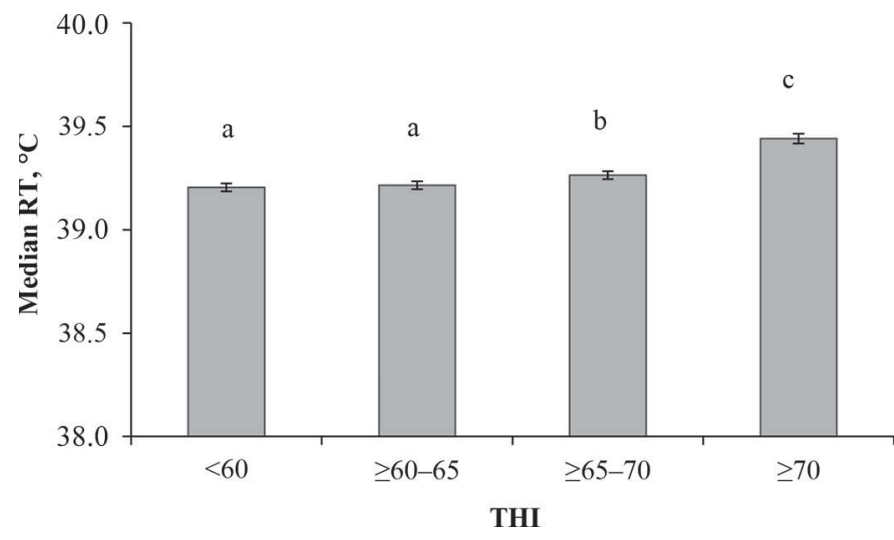

Figure 2. Least squares means $( \pm \mathrm{SE})$ of daily median reticular temperature (RT; $\mathrm{n}=28$ cows) in dependence of daily mean temperature-humidity index (THI; different letters indicate differences at $P$ $<0.05)$.

was found in summer when compared with spring and autumn (Bewley et al., 2008a). The authors proposed that this might be caused by adaptation mechanisms to alleviate heat load during hot conditions (i.e., a reduced feed intake and a shift of the blood flow from the body core to the periphery). However, a greater WI in dairy cows during summer months might be more likely to counteract the rise of RT.

Correlation coefficients between daily median RT and daily mean THI were $\mathrm{r}=-0.08, \mathrm{r}=-0.03, \mathrm{r}=0.06$, and $\mathrm{r}=0.22(P<0.001)$ for THI classes $<60, \geq 60$ to $65, \geq 65$ to 70 , and $\geq 70$, respectively (Table 3 ). A similar threshold was found by Nabenishi et al. (2011) who reported a positive correlation $(\mathrm{r}=0.30)$ between vaginal temperature and maximum THI during a hot period (THI 72 to 81), but a negative correlation during a cold period ( $\mathrm{r}=-0.08$; THI 48 to 69$)$. Araki et al. (1984) did not determine a relationship $(\mathrm{r}=0.0$ to -0.03$)$ between vaginal temperatures of dairy cows and the ambient THI, which might be explained by a positive correlation between BT and temperature $(\mathrm{r}=0.41$ to

Table 3. Correlation coefficients (r) between reticular temperature (RT) and daily mean temperature-humidity index (THI) and daily milk yield differentiated by THI and milk yield classes

\begin{tabular}{llr}
\hline Item & \multicolumn{1}{c}{ Class } & \multicolumn{1}{c}{$\mathrm{r}$} \\
\hline Daily mean THI & $<60$ & $0.18^{* * *}$ \\
& $\geq 60$ to 65 & $-0.08^{* * *}$ \\
& $\geq 65$ to 70 & $-0.03^{* * *}$ \\
& $\geq 70$ & $0.06^{* * *}$ \\
Daily milk yield, $\mathrm{kg}$ & $<30$ & $0.22^{* * *}$ \\
& $\geq 30$ to 35 & $-0.15^{* * *}$ \\
& $\geq 35$ to 40 & $0.08^{* * *}$ \\
& $\geq 40$ & $0.03^{* * *}$ \\
& & $-0.18^{* * *}$ \\
\hline
\end{tabular}

\footnotetext{
*** $P<0.001$
}

0.46) on the one hand, but a negative correlation to $\mathrm{RH}$ $(\mathrm{r}=-0.38$ to -0.40$)$ on the other hand. The ambient $\mathrm{RH}$ is of major importance in hot and humid climatic zones. These are characterized by a high $\mathrm{RH}$, which strongly limits evaporation in dairy cattle (Bohmanova et al., 2007). Under moderate climatic conditions, the relevance of temperature might be greater than that of RH. Vickers et al. (2010) reported correlations between THI and rectal $(\mathrm{r}=0.14)$ and vaginal $(\mathrm{r}=0.26)$ temperatures, which are similar to coefficients between THI and RT found in this study when THI $\geq 70$. Even though Vickers et al. (2010) interpreted the correlations as too low and without a relationship between THI and the BT measurements, we assume that the coefficient in the present study already indicates a considerable relationship.

\section{Effect of Milk Yield and Its Interaction with Climatic Conditions on Reticular Temperature}

Generally, milk production is accompanied with the production of metabolic heat (Berman et al., 1985). Specifically, high-yielding dairy cows $(31.6 \mathrm{~kg}$ of milk/d) were found to produce $48 \%$ more heat than nonlactating cows (Purwanto et al., 1990). At the same time, this leads to increasing BT of high-yielding dairy cows (Srikandakumar and Johnson, 2004).

Milk Yield. Averaged over the study period, dairy cows were on average $( \pm \mathrm{SD})$ 110.9 DIM $( \pm 79.3)$ and yielded daily $35.2 \mathrm{~kg}( \pm 9.1)$ milk (Table 1$)$. For farm 1,2 , and 3 , cows were on average $( \pm \mathrm{SD}) 95.0( \pm 57.4)$, $219( \pm 27)$, and $130.6( \pm 63.9)$ DIM and had a mean $( \pm \mathrm{SD})$ milk yield of $36.3 \mathrm{~kg}( \pm 10.4), 35.3( \pm 5.2)$, and $33.1( \pm 6.8)$, respectively. Daily milk production and DIM $(P<0.001)$ as well as their interaction $(P$ $=0.004$ ) influenced the daily median RT (Table 2 ). Unexpectedly, the daily median RT was found to be greater when milk yield was $<30 \mathrm{~kg}\left(39.3^{\circ} \mathrm{C}\right)$ compared with $\geq 40 \mathrm{~kg}\left(39.2^{\circ} \mathrm{C} ; P<0.001\right.$; Figure 3$)$. Studies using other methods of BT measurement methods reported contrary results. For example, Igono et al. (1985) found significantly greater milk temperatures for high-yielding lactating cows $\left(39.1^{\circ} \mathrm{C}\right)$ compared with cows with a low milk yield $\left(37.4^{\circ} \mathrm{C}\right)$. Using the vaginal temperature, Araki et al. (1984) found greater temperatures for early and late lactating cows than for dry cows under constant climatic conditions of around THI 75. When comparing high and low yielding breeds, Srikandakumar and Johnson (2004) found significantly greater rectal temperatures for Holstein cows $\left(39.18^{\circ} \mathrm{C}\right.$; $18.33 \mathrm{~kg} / \mathrm{d})$ than for Jersey $\left(38.73^{\circ} \mathrm{C} ; 12.17 \mathrm{~kg} / \mathrm{d}\right)$ or Australian Milking Zebu cows $\left(38.67^{\circ} \mathrm{C} ; 12.5 \mathrm{~kg} / \mathrm{d}\right)$. In the study of Liang et al. (2013), milk yield did not have a direct effect on RT; however, they observed 


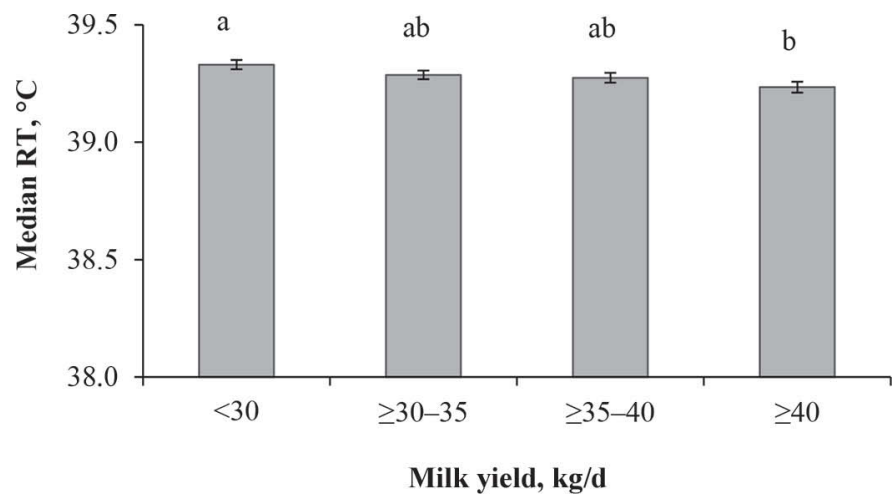

Figure 3. Least squares means $( \pm \mathrm{SE})$ of daily median reticular temperature (RT; $\mathrm{n}=28$ cows) in dependence of the daily milk yield class (different letters indicate differences at $P<0.05$ ).

greater RT $\left(40.2^{\circ} \mathrm{C}\right)$ for Holstein cows when compared with crossbreed cows $\left(40.0^{\circ} \mathrm{C}\right)$ and assumed that the effect of milk yield was dependent on breeds, differing in production level. This might be mainly explained by the high feed intake in high-yielding dairy cows, which consequently causes an increased ruminal heat production and RT (Liang et al., 2013).

In this study, milk yield and median RT were even negatively correlated for high-yielding cows. Correlation coefficients between daily median RT and daily milk yield ranged from $\mathrm{r}=-0.08(P<0.001)$ for milk yields $<30 \mathrm{~kg}$, to $\mathrm{r}=0.03(P<0.001)$ for $\geq 30$ to $35 \mathrm{~kg}$ and $\geq 35$ to $40 \mathrm{~kg}$, to $\mathrm{r}=-0.18(P<0.001)$ for $\geq 40 \mathrm{~kg}$ milk yield (Table 3 ). This contrary effect of milk yield on RT within the same breed might be explained by the low variation in milk yield in the current study. The average daily yields ranged only to a small extent from 33.1 to $36.3 \mathrm{~kg} / \mathrm{d}$ between the 3 farms in the present study. Effects of climatic conditions dependent on performance might rather be investigated when comparing high- and low-yielding breeds. Furthermore, as the WI in dairy cows affects their RT strongly (Bewley et al., 2008b) and increasing milk yield is associated with an increasing WI (Holter and Urban, 1992), the effect of metabolic heat on RT due to higher milk production seems to be compensated by an increasing WI, which will be discussed in detail below.

Interaction of Milk Yield and Climatic Conditions. Given the excessive metabolic heat production, high-yielding dairy cows are suggested to be highly sensitive to heat stress (Renaudeau et al., 2012), as dissipation of the additional heat to maintain core BT during thermal load is very limited. In our study, the interactions between daily THI and daily milk yield as well as between daily THI and DIM influenced the daily median RT $(P<0.001$; Table 2$)$. In agreement,
Liang et al. (2013) found increasing differences in RT between low- and high-yielding cows with rising temperature. Within the milk yield class $<30 \mathrm{~kg}, \mathrm{RT}$ did not differ between the THI classes (Figure 4). For all other milk yield classes, greatest RT $\left(39.5^{\circ} \mathrm{C}\right)$ was measured when daily THI $\geq 70(P<0.001)$. Again, this indicated that RT increase above the threshold of THI $=70$, particularly for dairy cows with $>30 \mathrm{~kg}$ daily milk yield. Igono et al. (1988) found greater milk temperatures for high- $\left(38.1\right.$ to $\left.38.2^{\circ} \mathrm{C}\right)$ than for low- $(35.9$ to $\left.36.1^{\circ} \mathrm{C}\right)$ producing cows with THI $<60(P<0.05)$. In both groups (high and low production), average milk temperatures increased when $\mathrm{THI}>61\left(38.4^{\circ} \mathrm{C}, 36.5^{\circ} \mathrm{C}\right)$ and even further when THI $>71\left(38.7^{\circ} \mathrm{C}, 36.7^{\circ} \mathrm{C}\right)$. The difference was significant between THI classes $(P<$ $0.05)$.

\section{Effect of Water Intake on Reticular Temperature}

Beside heat production through fermentation, RT values are influenced by WI of dairy cattle (Bewley et al., 2008b), which has to be considered carefully when interpreting RT measurements. As presented in Table 4 , these cows showed a mean $( \pm \mathrm{SD})$ of 8.03 drinking bouts/d $( \pm 2.12)$, with an average $( \pm \mathrm{SD})$ duration between the bouts of $186.5 \mathrm{~min}( \pm 145.4)$. Mean $( \pm \mathrm{SD})$ consumption was $11.6 \mathrm{~L} /$ bout $( \pm 5.7)$. On average $( \pm \mathrm{SD})$, RT decreased by $3.2^{\circ} \mathrm{C}( \pm 1.5)$ until $10 \mathrm{~min}$ after WI. Figure 5 presents the course of RT until 120 min after WI. Similar to these results, lowest RT was observed by Bewley et al. (2008b) immediately after WI, after which it increased steadily until it reached the level before drinking after more than $3 \mathrm{~h}$.

The drop in RT increased with rising amount of water consumed $(P<0.001)$ and reached a mean temperature change of $4^{\circ} \mathrm{C}$ when more than $15 \mathrm{~L} /$ bout was ingested (Figure 6). If less than $5 \mathrm{~L} /$ bout was consumed, the accordant value was $1.8^{\circ} \mathrm{C}$. Bewley et al. (2008b) found a stronger decline in RT after WI of up to $9.2^{\circ} \mathrm{C}$. The main difference to the voluntary WI studied here is that cows were drenched with greater amounts of WI $(25.5$ and $18.5 \mathrm{~kg}$ ) in the mentioned study. This effect is confirmed by the positive correlation of $\mathrm{r}=0.60(P<$ 0.001 ) between the amount of WI and the drop in RT after WI in our study. On the other hand, Bewley et al. (2008b) found that water temperature has a major influence on the decrease of RT after WI. Thus, a water temperature of $5.1^{\circ} \mathrm{C}$ led to a maximum drop in RT of $9.2^{\circ} \mathrm{C}$, whereas RT decreased about 6.9 and $2.2^{\circ} \mathrm{C}$ with water temperatures of 18.2 and $34.3^{\circ} \mathrm{C}$, respectively.

Cunningham et al. (1992) found decreases in RT after WI between 1.3 to $12.8^{\circ} \mathrm{C}$ depending on the level of RT before WI. The amount of water $[$ mean $( \pm \mathrm{SD})$, 
Table 4. Descriptive statistics of water intake (WI) parameters and decrease of reticular temperature (RT) 10 min after WI of dairy cows $(\mathrm{n}=10)$

\begin{tabular}{lrrcc}
\hline Item & Mean & \multicolumn{1}{c}{ SD } & Minimum & Maximum \\
\hline Drinking bouts/d & 8.0 & 2.1 & 3 & 16 \\
Drinking interval, min & 186.5 & 145.4 & 0 & 740 \\
WI/bout, L & 11.6 & 5.7 & 0.1 & 27.2 \\
RT decrease after WI, ${ }^{\circ} \mathrm{C}$ & 3.2 & 1.5 & 0 & 7.8 \\
\hline
\end{tabular}

$21.1 \mathrm{~kg}( \pm 3.9)]$, delivered by drenching, and the water temperature $\left(1.1^{\circ} \mathrm{C}\right)$ are similar to the treatment with cold water in the study of Bewley et al. (2008b). A previous study found RT not to drop below $32^{\circ} \mathrm{C}$ after WI from a pre-drinking level between 39 to $40^{\circ} \mathrm{C}$, when water temperatures ranged between 4 to $5^{\circ} \mathrm{C}$ (Simmons et al., 1965). Even though WI was only measured in a limited number of animals and only on 1 of the 3 farms, to our knowledge this is the first study in which the effects of voluntary WI of lactating dairy cows on RT were measured. Future studies should consider the effects of voluntary WI and TMR composition, as well as water temperature on the RT measurements.

The duration until RT reached the initial level after WI also increased with rising amount of WI (Figure 7). When $\leq 5 \mathrm{~L} /$ bout was consumed, $\mathrm{RT}$ reached the initial level at $30 \%$ of the drinking events within $30 \mathrm{~min}$ and at another 30\% within 60 min. For bouts with more than $15 \mathrm{~L}$ of intake, RT took more than 120 min in $50 \%$ of the records to reach the level measured before WI. Previous studies investigated the effect of WI on RT by providing equal amounts of water with different temperatures to the cows. Bewley et al. (2008b) reported that RT did not return to the pre-drinking level within $3 \mathrm{~h}$, when the cows received $25.2 \mathrm{~L}$ of water with $7.6^{\circ} \mathrm{C}$ or $18.9 \mathrm{~L}$ with $5^{\circ} \mathrm{C}$. Again, this might be caused by the greater amount of WI drenched to the cows, compared with smaller amounts of WI consumed voluntarily in our study. Yamada et al. (2001) found that RT already returned to the initial temperature before drinking after 20 min, even though it decreased by approximately $6^{\circ} \mathrm{C}$ after WI. In total, comparisons between this and other previous studies are limited considering the effects of different amounts of WI on RT.

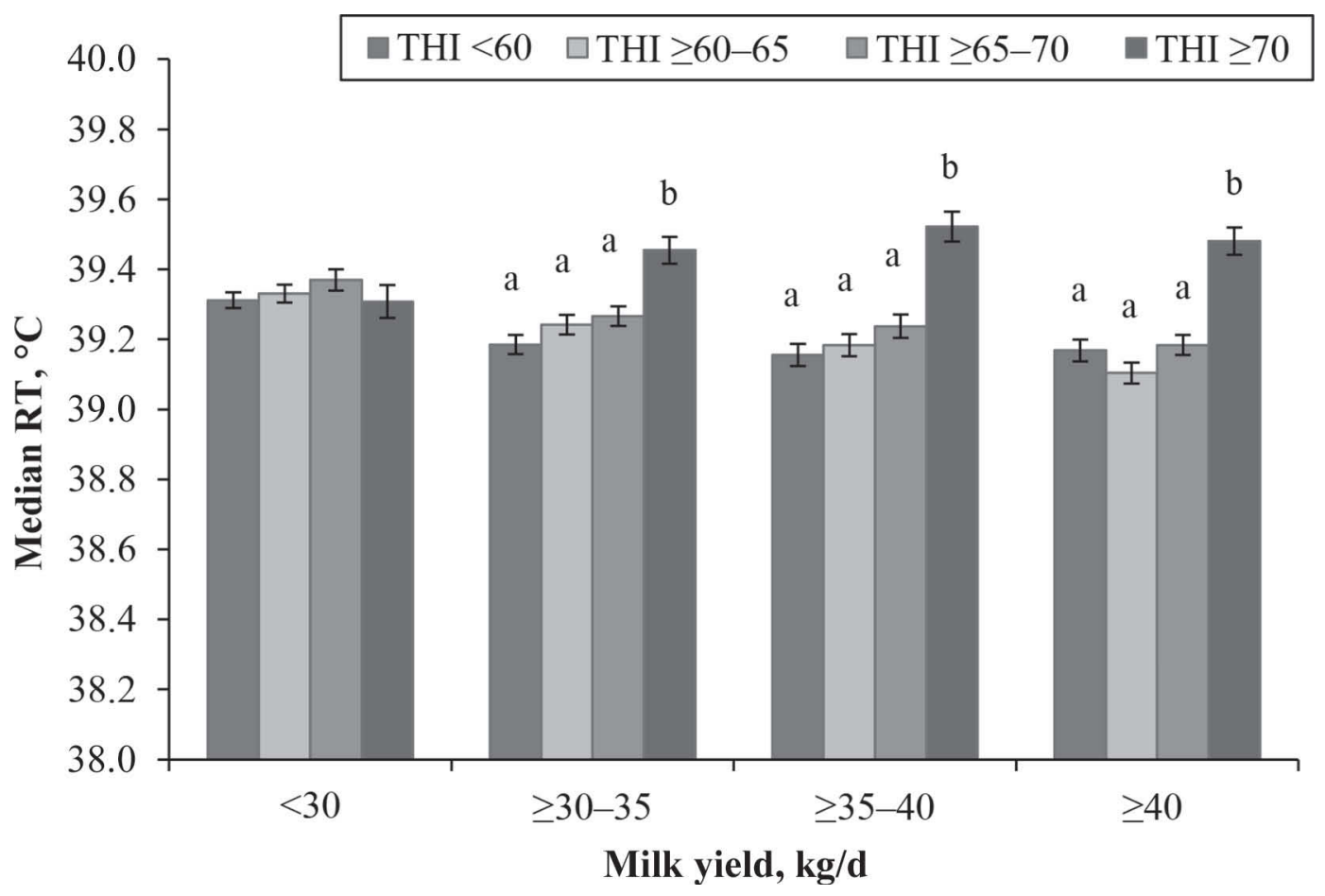

Figure 4. Least squares means $( \pm \mathrm{SE})$ of daily median reticular temperature (RT; $\mathrm{n}=28$ cows) in dependence of the daily temperature-humidity index (THI) classes differentiated by the daily milk yield class (different letters within milk yields classes indicate differences at $P<0.05$ ). 


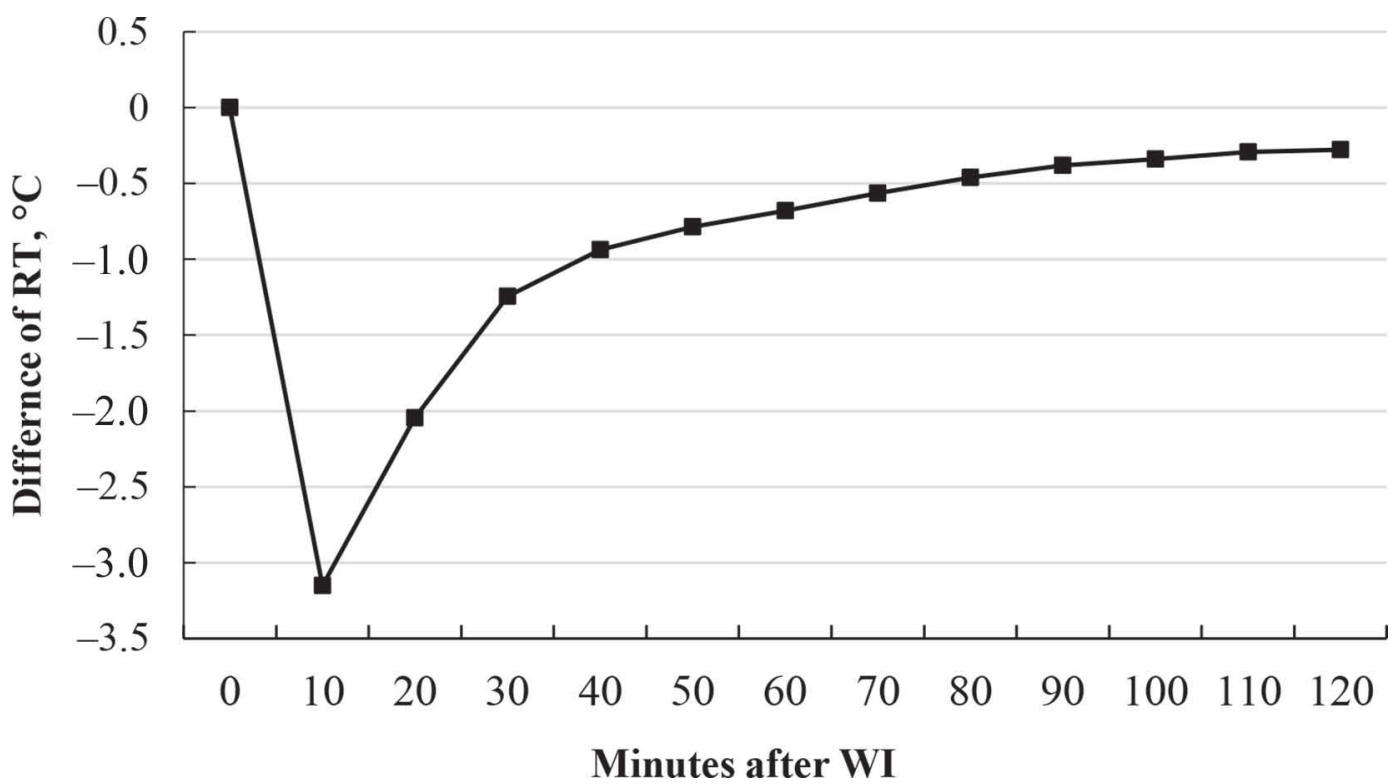

Figure 5. Difference of reticular temperature (RT; $\mathrm{n}=10 \mathrm{cows}$ ) until $120 \mathrm{~min}$ after water intake (WI) to the RT at the time of WI for dairy cows (LSM).

\section{CONCLUSIONS}

The results of the present study confirmed that even dairy cows under moderate climatic conditions are already exposed to heat stress during the summer months. Reticular temperature increased when the THI threshold of 65 was exceeded. A further increase was noted when THI $\geq 70$. Concerning the effect of performance, particularly the interaction of high milk yields and ambient heat conditions resulted in increasing RT. Voluntary WI influenced the course of RT sizably depending on the consumed amount of water. Thus, the effects of WI and milk yield have to be considered

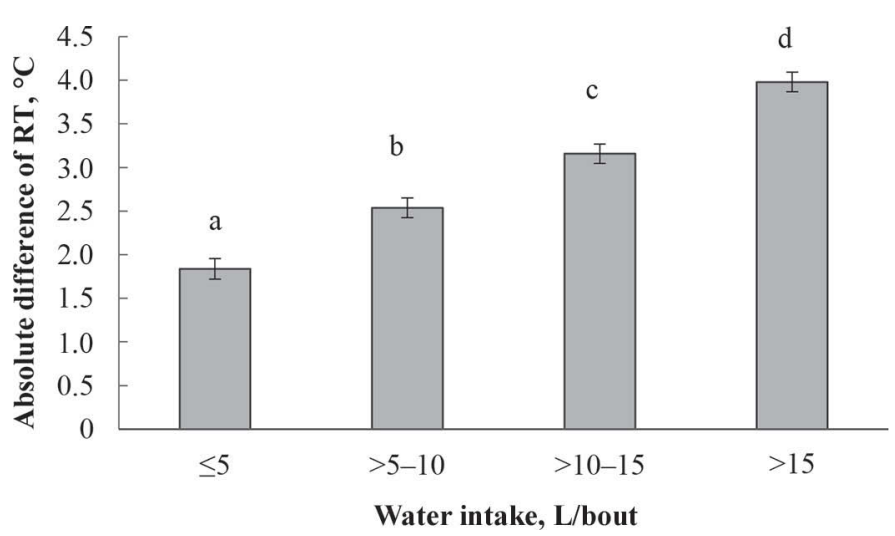

Figure 6. Difference of reticular temperature (RT; $\mathrm{n}=10 \mathrm{cows}$ ) prior and $10 \mathrm{~min}$ after water intake (WI) in dependence of the amount of WI (LSM $\pm \mathrm{SE}$; different letters indicate differences at $P<0.05)$. carefully when RT is used to detect hyperthermia in dairy cattle.

\section{ACKNOWLEDGMENTS}

This study was funded by the Ministry of Science and Culture of Lower Saxony within the project Climate Impact and Adaptation Research in Lower Saxony (KLIFF). The authors thank the participating farmers and the Institute of Animal Nutrition of the Friedrich-

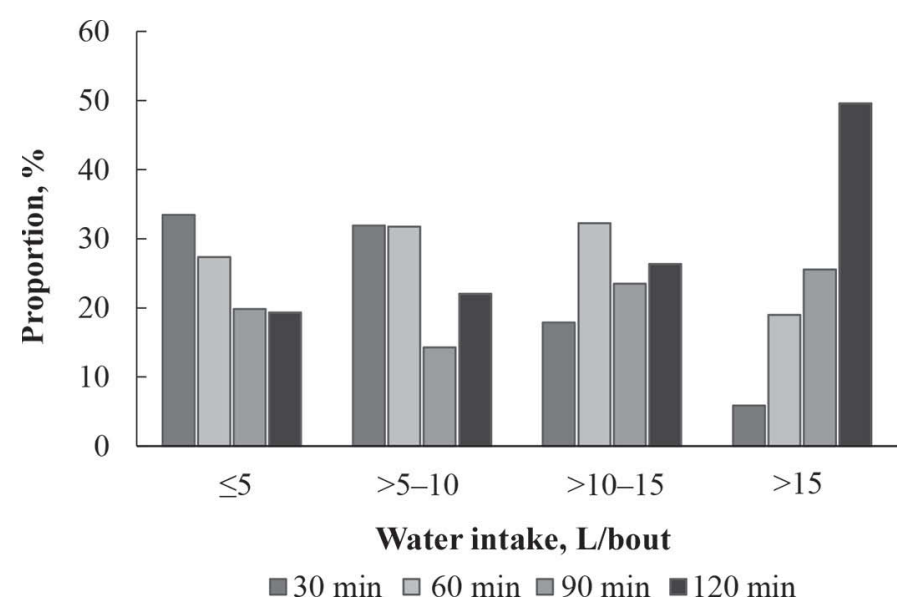

Figure 7. Proportion of drinking bouts until reticular temperature (RT; $\mathrm{n}=10$ cows) reached the initial level before drinking after different durations $(30,60,90$, and $120 \mathrm{~min})$ in dependence of the amount of water intake (WI). 
Loeffler-Institute for their cooperation and support during the study.

\section{REFERENCES}

Ammer, S., C. Lambertz, and M. Gauly. 2016. Comparison of different measuring methods for body temperature in lactating cows under different climatic conditions. J. Dairy Res. 83:165-172. http:// dx.doi.org/10.1017/S0022029916000182.

Araki, C. T., R. M. Nakamura, L. Kam, and N. Clarke. 1984. Effect of lactation on diurnal temperature patterns of dairy cattle in hot environments. J. Dairy Sci. 67:1752-1760. http://dx.doi. org/10.3168/jds.S0022-0302(84)81501-5.

Berman, A., Y. Folman, M. Kaim, M. Mamen, Z. Herz, D. Wolfenson, A. Arieli, and Y. Graber. 1985. Upper critical temperatures and forced ventilation effects for high-yielding dairy cows in a subtropical climate. J. Dairy Sci. 68:1488-1495. http://dx.doi.org/10.3168/ jds.S0022-0302(85)80987-5.

Bewley, J. M., M. E. Einstein, M. W. Grott, and M. M. Schutz. 2008a. Comparison of reticular and rectal core body temperatures in lactating dairy cows. J. Dairy Sci. 91:4661-4672. http://dx.doi. org/10.3168/jds.2007-0835.

Bewley, J. M., M. W. Grott, M. E. Einstein, and M. M. Schutz. 2008b. Impact of intake water temperatures on reticular temperatures of lactating dairy cows. J. Dairy Sci. 91:3880-3887. http://dx.doi. org/10.3168/jds.2008-1159.

Bitman, J., A. Lefcourt, D. L. Wood, and B. Stroud. 1984. Circadian and ultradian temperature rhythms of lactating dairy cows. J. Dairy Sci. 67:1014-1023. http://dx.doi.org/10.3168/jds.S00220302(84)81400-9.

Bohmanova, J., I. Misztal, and J. B. Cole. 2007. Temperature-humidity indices as indicators of milk production losses due to heat stress. J. Dairy Sci. 90:1947-1956. http://dx.doi.org/10.3168/jds.2006-513.

Brown-Brandl, T. M., T. Yanagi, H. Xin, R. S. Gates, R. A. Bucklin, and G. S. Ross. 2003. A new telemetry system for measuring core body temperature in livestock and poultry. Appl. Eng. Agric. 19:583-590.

Brügemann, K., E. Gernand, U. König von Borstel, and S. König 2012. Defining and evaluating heat stress thresholds in different dairy cow production systems. Arch. Anim. Breed. 55:13-24.

Cunningham, M. D., F. A. Martz, and C. P. Merilan. 1992. Effect of drinking-water temperature upon ruminant digestion, intraruminal temperature, and water consumption of nonlactating dairy cows. J. Dairy Sci. 47:382-385. http://dx.doi.org/10.3168/jds. S0022-0302(64)88671-9.

Dikmen, S., and P. J. Hansen. 2009. Is the temperature-humidity index the best indicator of heat stress in lactating dairy cows in a subtropical environment? J. Dairy Sci. 92:109-116. http://dx.doi. org/10.3168/jds.2008-1370.

Gauly, M., H. Bollwein, G. Breves, K. Brügemann, S. Dänicke, G. Daș, J. Demeler, H. Hansen, J. Isselstein, S. König, M. Lohölter, M. Martinsohn, U. Meyer, M. Potthoff, C. Sanker, B. Schröder, N. Wrage, B. Meibaum, G. von Samson-Himmelstjerna, H. Stinshoff, and C. Wrenzycki. 2013. Future consequences and challenges for dairy cow production systems arising from climate change in Central Europe - a review. Animal 7:843-859. http://dx.doi. org/10.1017/S1751731112002352.

Hicks, L. C., W. S. Hicks, R. A. Bucklin, J. K. Shearer, D. R. Bray, P. Soto, and V. Carvalho. 2001. Comparison of methods of measuring deep body temperature of dairy cows. Pages $432-438$ in 6th Int. Symp. ASAE, Louisville, KY. Am. Soc. Agric. Biol. Eng., St. Joseph, MI.

Holter, J. B., and W. E. J. Urban. 1992. Water partitioning and intake prediction in dry and lactating Holstein cows. J. Dairy Sci. 75:14721479. http://dx.doi.org/10.3168/jds.S0022-0302(92)77904-1.
Igono, M. O., H. D. Johnson, B. J. Steevens, W. A. Hainen, and M. D. Shanklin. 1988. Effect of season on milk temperature, milk growth hormone, prolactin, and somatic cell counts of lactating cattle. Int. J. Biometeorol. 32:194-200.

Igono, M. O., B. J. Steevens, M. D. Shanklin, and H. D. Johnson. 1985. Spray cooling effects on milk production, milk, and rectal temperatures of cows during a moderate temperate summer season. J. Dairy Sci. 68:979-985. http://dx.doi.org/10.3168/jds S0022-0302(85)80918-8.

Kadzere, C. T., M. R. Murphy, N. Silanikove, and E. Maltz. 2002. Heat stress in lactating dairy cows: A review. Livest. Prod. Sci. 77:59-91. http://dx.doi.org/10.1016/S0301-6226(01)00330-X.

Lambertz, C., C. Sanker, and M. Gauly. 2014. Climatic effects on milk production traits and somatic cell score in lactating Holstein-Friesian cows in different housing systems. J. Dairy Sci. 97:319-329. http://dx.doi.org/10.3168/jds.2013-7217.

Liang, D., C. L. Wood, K. J. McQuerry, D. L. Ray, J. D. Clark, and J. M. Bewley. 2013. Influence of breed, milk production, season, and ambient temperature on dairy cow reticulorumen temperature. J. Dairy Sci. 96:5072-5081. http://dx.doi.org/10.3168/jds.2012-6537.

Nabenishi, H., H. Ohta, T. Nishimoto, T. Morita, K. Ashizawa, and Y. Tsuzuki. 2011. Effect of the temperature-humidity index on body temperature and conception rate of lactating dairy cows in southwestern Japan. J. Reprod. Dev. 57:450-456. http://dx.doi. org/10.1262/jrd.10-135T.

NRC. 1971. A Guide to Environmental Research on Animals. National Academy of Sciences, Washington, DC.

Purwanto, B. P., Y. Abo, R. Sakamoto, F. Furumoto, and S. Yamamoto. 1990. Diurnal patterns of heat production and heart rate under thermoneutral conditions in Holstein Friesian cows differing in milk production. J. Agric. Sci. 114:139-142. http://dx.doi. org/10.1017/S0021859600072117.

Renaudeau, D., A. Collin, S. Yahav, V. de Basilio, J. L. Gourdine, and R. J. Collier. 2012. Adaptation to hot climate and strategies to alleviate heat stress in livestock production. Animal 6:707-728. http://dx.doi.org/10.1017/S1751731111002448.

Simmons, K. R., A. E. Dracy, and W. O. Essler. 1965. Diurnal temperature patterns in unrestrained cows. J. Dairy Sci. 48:1490-1493. http://dx.doi.org/10.3168/jds.S0022-0302(65)88504-6.

Srikandakumar, A., and E. H. Johnson. 2004. Effect of heat stress on milk production, rectal temperature, respiratory rate and blood chemistry in Holstein, Jersey and Australian Milking Zebu cows. Trop. Anim. Health Prod. 36:685-692. http://dx.doi.org/10.1023/ B:TROP.0000042868.76914.a9.

Vickers, L. A., O. Burfeind, M. von Keyserlingk, D. M. Veira, D. M. Weary, and W. Heuwieser. 2010. Technical note: Comparison of rectal and vaginal temperatures in lactating dairy cows. J. Dairy Sci. 93:5246-5251. http://dx.doi.org/10.3168/jds.2010-3388.

West, J. W. 1999. Nutritional strategies for managing the heat-stressed dairy cow. J. Anim. Sci. 77:21-35.

West, J. W. 2003. Effects of heat-stress on production in dairy cattle. J. Dairy Sci. 86:2131-2144. http://dx.doi.org/10.3168/jds.S00220302(03)73803-X.

West, J. W., G. M. Hill, J. M. Fernandez, P. Mandebvu, and B. G. Mullinix. 1999. Effects of dietary fiber on intake, milk yield, and digestion by lactating dairy cows during cool or hot, humid weather. J. Dairy Sci. 82:2455-2465. http://dx.doi.org/10.3168/jds. S0022-0302(99)75497-4.

West, J. W., B. G. Mullinix, and J. K. Bernard. 2003. Effects of hot, humid weather on milk temperature, dry matter intake, and milk yield of lactating dairy cows. J. Dairy Sci. 86:232-242. http:// dx.doi.org/10.3168/jds.S0022-0302(03)73602-9.

Yamada, A., M. Sutoh, and T. Imura. 2001. The changes of rumen temperature with grazing behavior in the daytime. Grassl. Sci. $47: 491-493$ 